\title{
Cranial Capacity in an Adult Sri Lankan Population: Sexual Dimorphism and Ethnic Diversity
}

\author{
Capacidad Craneal en la Población Cingalés Adulta: Dimorfismo Sexual y Diversidad Étnica
}

Ilayperuma $\mathbf{I}$.

ILAYPERUMA, I. Cranial capacity in an adult Sri Lankan population: sexual dimorphism and ethnic diversity. Int. J. Morphol., 29(2):479-484, 2011.

SUMMARY: Cranial capacity exerts a close correlation with the volume of the brain. A large body of evidence shows a clear racial variation in cranial dimensions. Therefore detailed knowledge of the population specific data on biometric features of the cranial cavity is important in the study and comparison of the crania of populations from different racial backgrounds, assessing growth and development of an individual and in the diagnosis of any abnormalities of cranial size and shape. Despite its significance, little is known concerning the cranial capacity in Sri Lankans. Hence, the present study was undertaken to establish the cranial capacity in an adult Sri Lankan population. A total of 210 subjects with an age span of 20-23 years were included in the study. The cranial length, breadth and auricular head height of the subjects were recorded using a digital sliding caliper and Todd's head spanner capable of measuring to the nearest $0.01 \mathrm{~mm}$. The cranial capacity was calculated using external dimensions of the skulls (Lee \& Pearson, 1901; Williams et al., 2000). The findings of the study indicated significant sexual differences in the mean cranial capacity (male: $1421.12 \pm 171.69$, female: $1300.95 \pm 158.18$ ). Positive correlations between cranial capacity and cranial dimensions were observed. Linear regression models for the prediction of cranial capacity were formulated for both sexes. The results of this study highlight the racial and sexual differences in cranial capacity in an adult Sri Lankan population. The data will be of immense use in clinical, medico-legal, anthropological and archeological studies.

KEY WORDS: Cranial capacity; Linear dimensions; Regression analysis; Sri Lanka.

\section{INTRODUCTION}

It is well accepted that the cranial capacity exerts a strong correlation with the volume of the brain (Gault et al., 1988; Wolf et al., 2003; Mazonakis et al., 2004). Variety of methodologies have been employed to study the cranial capacity either on macerated dry skulls or in living subjects. It has been measured directly by packing method in which the cranial cavity is filled with filling material like sand, paraffin wax or mustard seed and then measuring it (Hwang et al., 1995; Manjunath, 2002a). Indirect methods of estimating cranial capacity employ a number of formula that uses external dimension of either macerated skulls, living subjects or antero-posterior and lateral direct roentgenograms of the skulls (Lee \& Pearson, 1901; Haack \& Meihoff, 1971; Williams et al., 2000; Manjunath, 2002a). With the recent advent of the science and technology fully automated techniques such as Structural Image Evaluation using Normalisation of Atrophy (SIENA) which performs segmentation of brain from non-brain tissue in the head to estimate the outer skull surface have been used to evaluate the cranial capacity (Mayhew \& Olsen, 1991; Manjunath, 2002a).

Evidence shows a clear racial variation in the cranial dimensions and the cranial capacity among different populations such as Koreans, Caucasians, Indians, Turkman and native Fars groups, Turkey and Zulu populations (Dekaban, 1977; Thomas et al., 1980; Ricklan \& Tobias, 1986; Hwang et al.; Manjunath, 2002b; Golalipour et al., 2005; Acer et al., 2007a). Therefore, knowledge on the cranial capacity is important in the study and comparison of the crania of populations from different racial, geographic and dietary backgrounds. Such information is also useful in studies of primate phylogeny. In clinical practice, population and age specific data on cranial capacity gives an indication of growth and development of an individual and also any abnormalities of cranial size and shape which will provide new information to medical and health professionals (Haack \& Meihoff; Harper et al., 1984; del Sol, 2005). 
Although many formulae for prediction of cranial capacity from principal cranial dimensions have been proposed for different populations, there is concern regarding the accuracy of the use of population specific formulae on other human populations (Hwang et al.; Williams et al.; Acer et al., 2007a). It is obvious that there are no universally applicable formulae as the relationship between head dimensions and cranial capacity is influenced by the race, sex and age of an individual. Thus, the need for race, age and sex specific stature estimation formulae is proved beyond doubt (Krishan, 2007).

Despite its significance and practical use little is known concerning the cranial dimensions and cranial capacity in Sri Lankans, inhabitants of the South Asian country. Hence, this study was designed to elucidate the norms for cranial volume and to propose population and sexual specific regression formulae using the linear dimensions of the dry skulls.

\section{MATERIAL AND METHOD}

This study was conducted on 210 medical students (118 male and 92 female) of the Faculty of Medicine, University of Ruhuna, Galle, Sri Lanka. The subjects were apparently healthy and without any physical deformity. They were from different parts of the island belonging to different socio-economic status. The age of the subjects ranged from 20-23 years.

The following external linear dimensions of the skulls were recorded (Williams et al.):

1. Maximum cranial length (Glabella-inion length). It is defined as the straight distance between the most prominent point on the frontal bone above the root of the nose (glabella) and the most prominent portion of the occipital bone. This was measured by placing the anterior caliper tip on the glabella while allowing the posterior caliper tip to slide inferiorly along the median plain of the occipital bone until the maximum length was reached.

2. Maximum cranial breadth (maximum bi-parietal diameter). It is defined as the maximum distance between the most lateral points of the parietal bones. This was measured by allowing the both tips of the spreading caliper to slide down along the lateral aspects of the parietal bones until the maximum width was recorded.

Maximum antero-posterior cranial length and maximum cranial breadth were measured using a digital spreading caliper (Mitutoyo, Japan) capable of measuring to the nearest $0.01 \mathrm{~mm}$.

3. Maximum auricular head height. It is defined as the distance between the external acoustic meatus and the highest point of the vertex (bregma). The measurement was recorded on both sides using the Todd's head spanner.

The above measurements were recorded at a fixed time between $14.00-16.30$ hours to eliminate discrepancies due to diurnal variation. All the measurements were repeated thrice and the mean was taken for further analysis. Furthermore, the measurements were recorded by the same person to minimize the errors in methodology.

The cranial capacity was calculated using the following formula (Lee \& Pearson; Williams et al.):

Males: 0.000337(L-11) (B-11) (HT-11) + 406.01; Females: 0.000400(L-11) (B-11) (HT-11) + 206.60.

The degree of sexual divergence in cranial capacity was calculated as follows (Hwang et al.; Borgognini et al., 1986): The index of sexual dimorphism = male mean female mean/ male mean x $100 \%$.

Results were expressed as mean \pm SD and analyzed using the Statistical Package for Social Sciences (SPSS), 15 th version. A comparison of the mean values between the sexuals was performed using the t-test. $\mathrm{P}$ value $<0.05$ was considered statistically significant.

\section{RESULTS}

The mean ages of the study subjects (male: $21.03 \pm$ 0.88 ; female $21.27 \pm 0.89$ ) were not significantly different between the sexes (Table I). The mean cranial capacities vary significantly $(\mathrm{P}>0.05)$ between the sexes $(\mathrm{P}<0.001)$ (Table I).

The mean cranial dimensions of the skulls are summarized in Table I. Sexual differences with respect to the mean cranial length and cranial breadth were found to be significantly larger in males compared to females $(\mathrm{P}<0.001)$. The mean cranial height was larger in males compared to females although sexual difference was not statistically significant $(\mathrm{P}>0.05)$.

Correlation coefficient between cranial dimensions and the cranial capacity are depicted in Table II. Correlation coefficient between cranial capacity and all measured cranial 
Table I. Cranial dimensions of the study subjects.

\begin{tabular}{lcc}
\hline Characteristic & Male & Female \\
\hline Total number & 118 & 92 \\
Cranial capacity & $1421.12 \pm 171.69 *$ & $1300.95 \pm 158.18$ \\
Cranial length $(\mathrm{mm})$ & $180 \pm 11.12 *$ & $171.92 \pm 10.11$ \\
Cranial breadth $(\mathrm{mm})$ & $140.15 \pm 10.66 *$ & $136.15 \pm 11.02$ \\
Auricular head height $(\mathrm{mm})$ & $141.10 \pm 9.00$ & $135.38 \pm 12.16$ \\
\hline
\end{tabular}

$*(\mathrm{P}<0.05)$

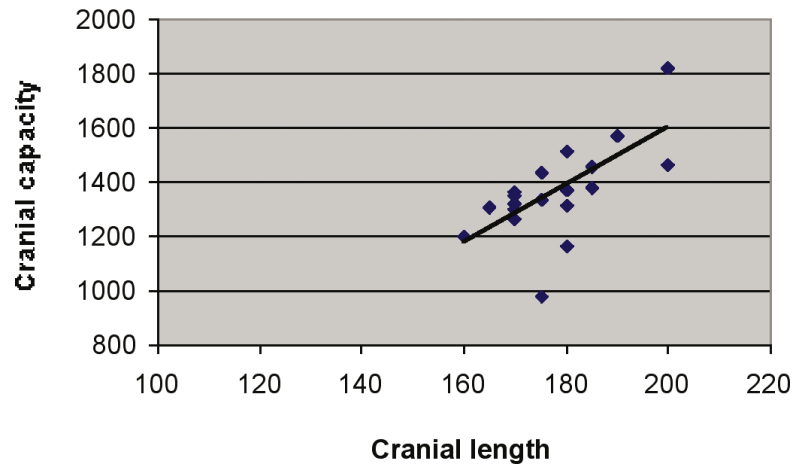

Fig. 1. Scatter plot and regression line demonstrating the relationship between cranial capacity and cranial length $(\mathrm{mm})$.

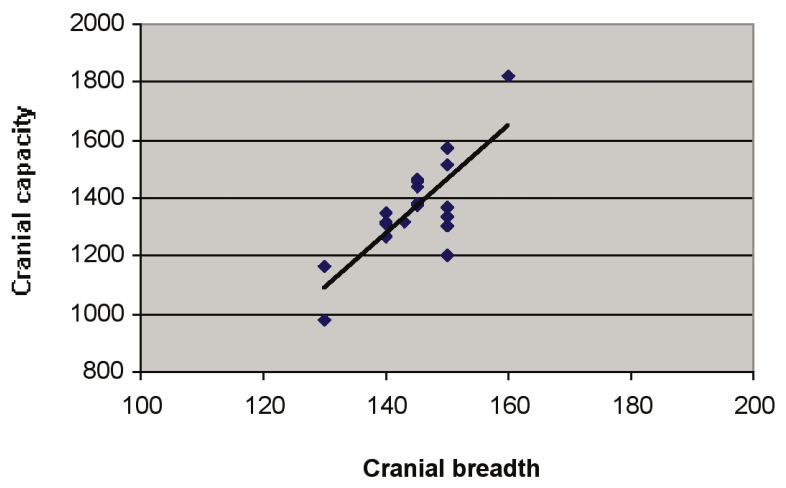

Fig. 2. Scatter plot and regression line demonstrating the relationship between cranial capacity and cranial breadth $(\mathrm{mm})$.

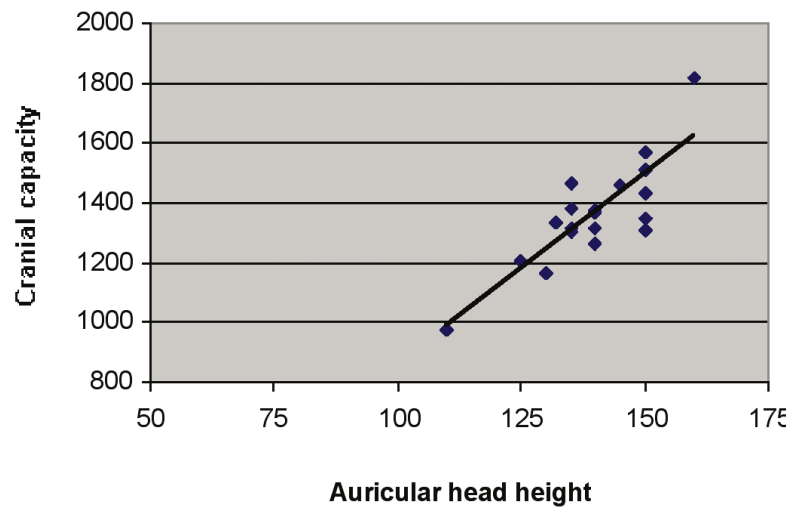

Fig. 3. Scatter plot and regression line demonstrating the relationship between cranial capacity and auricular head height $(\mathrm{mm})$.
Table II. Correlation coefficient between the cranial capacity (CC) and cranial dimensions.

\begin{tabular}{llll}
\hline Parameter & Male & Female & Both sex \\
\hline CC \& cranial length & 0.806 & 0.255 & 0.654 \\
CC \& cranial breadth & 0.663 & 0.839 & 0.780 \\
CC \& auricular head height & 0.882 & 0.884 & 0.835 \\
\hline
\end{tabular}

dimensions were found to be statistically significant and positive indicating a strong relationship between the above parameters. Auricular head height was shown to have the highest correlation with the cranial capacity. Scatter plots and regression lines demonstrating the relationship between cranial capacity and head dimensions are illustrated in Figs. 1- 3 .

Linear regression formulae for the prediction of cranial capacity using cranial dimensions were derived as follows:

Regression equation for prediction of cranial capacity from cranial length:

For male: $408.03+10.47$ (cranial length).

For female: $230.69+6.10$ (cranial length).

For both male and female (combined): $506.66+10.52$ (cranial length).

Regression equation for prediction of cranial capacity from cranial breadth:

For male: $1617.15+20.56$ (cranial breadth).

For female: $1227.59+17.92$ (cranial breadth).

For both male and female (combined): $1342.45+18.71$ (cranial breadth).

Regression equation for prediction of cranial capacity from auricular head height:

For male: $631.84+14.64$ (auricular head height).

For female: $200.02+10.81$ (auricular head height).

For both male and female (combined): $407.29+12.69$ (auricular head height).

\section{DISCUSSION}

The present study provides valuable new data pertaining to the cranial capacity and principal anatomical dimensions of the skulls in an adult Sri Lankan population. It is stated that the racial characters are most prominently observed in the skull (Krishan). Therefore cranial capacity is an important character for determining the racial difference (Hwang et al.; Manjunath, 2002a; Krishan). Variety of 
methodologies has been utilized in the assessment of ethnic and sexual differences of the skull. The non-metric parameters are subjective as non quantitative techniques are devised. On the other hand, features that can be expressed as actual measurements, like cranial capacity and cranial dimensions, provide more objective racial and sexual diversity assessment of the crania (Krishan).

Diverse craniometric approaches have been proposed and utilized to estimate the cranial capacity either on dry skulls or living subjects (Manjunath, 2002a). Over the course of this study cranial capacity was estimated based on the linear dimensions of the skulls. It was interesting to note that evaluation of results of a comparative study that employed three different approaches, namely, the stereologic, planimetric and cephalometry to asses the cranial volume, have demonstrated no statistically significant differences between such results (Acer et al., 2007b). The assessment of the cranial volume using cephalometry is reliable, relatively easy and quick to apply. Furthermore this approach has the added advantage as it does not require any sophisticated techniques. Taken together, cephalometry continues to be the most versatile technique in the investigations of the craniofacial skeleton (McIntyre \& Mossey, 2003; Vojdani et al., 2009).

The mean cranial capacity observed in this study (male: $1421.12 \pm 171.69$, female: $1300.95 \pm 158.18$ ) was greater than those observed for the Indians, Turkman, Native Fars and Turkey populations (Manjunath, 2002b; Golalipour et al., 2005; Acer et al., 2007) whereas it was smaller than those of the Koreans and Caucasians, (Hwang et al.; Dekaban) a finding that further reinforces the racial diversity in the cranial capacity. It is speculated that such population diversity in cranial capacity and cranial dimensions are attributed to race, age and geographical factors (Ricklan \& Tobias; Golalipour et al., 2003).

The linear regression models proposed for the prediction of cranial capacity are valid for the age group (20-23 years) of the study population. It has been clearly stated that cranial capacity varies with the age of an individual reaching its peak volume around 16-20 years of life (Knutson et al., 2001; Wolf et al.).

Sexual dimorphism is a vital component of the morphological variation among biological populations (Borgognini \& Repetto; Williams et al.). The index of sexual dimorphism in Sri Lankans (8.46\%) was shown to be higher than that of the Caucasians: $(7.95 \%)$ and lower than the Koreans: 10.3\%; Turkmans: $13.61 \%$; Native Fars: 11.22\%; and Turkey population: $10.06 \%$ (Hwang et al.; Dekaban,; Golalipour et al., 2005; Acer et al., 2007a). The sexual differences in cranial dimensions emphasize the significance of applying the anatomical variation data to an individual subject in a given population. Since the rate of skeletal maturity in males and females vary during the course of growth, alternative formulae for the sexes are needed (Williams et al.). Furthermore, the importance of sexual determination in personal identification, cannot be over emphasized in medico-legal, archeological and anthropological studies, particularly when the body is recovered in an advanced stage of decomposition where only fragments of skeletal remains are available.

The significance of sex, age and population specific craniometric data is multifold. It provides important evidence in a crime scene investigation in establishing the identity of a criminal. In addition, the linear dimensions of the skulls will be of immense use in attempts to reconstruct appearances of cranium in life of individuals represented only by cranial remains in anthropological studies (Krishan).

Clinically, knowledge on the cranial capacity of a specific population could be of potential application in the estimation of brain atrophy as variations of brain volume often reflect pathological states (Harper et al.). In addition, cranial capacity helps in estimating the cranio-encephalic space which gives an indication of the average width of the space between the skull and the brain (Harper et al.). The index of brain atrophy was shown to be varied with the cerebral arteriosclerosis and conditions that cause mental deterioration (Harper et al.).

In pediatric practice, the volume of the cranium is a measure of considerable interest. This is particularly important during the first few years of life as during this period the skull is growing rapidly. Furthermore, in the interpretation of skull radiographs there is often a need for baseline set of data for standard skull size, especially where the possibility of cerebral atrophy or mild hydrocephalus or abnormality in the shape of the skull is in question (Ricklan $\&$ Tobias). Taken together the evidence suggests that the value of population, sex and age specific data on cranial capacity cannot be underestimated.

ILAYPERUMA, I. Capacidad craneal en la población cingalés adulta: dimorfismo sexual y diversidad étnica. Int. J. Morphol., 29(2):479-484, 2011.

RESUMEN: La capacidad craneal indica una estrecha relación con el volumen cerebral. Existen numerosas evidencias que muestran una variacion racial en las dimensiones craneanas. Así, un conocimiento detallado de datos biométricos de la cavidad craneana en poblaciones y una comparación de cráneos en 
individuos de diferentes etnias permiten evaluar el crecimiento y desarrollo en un individuo y el diagnóstico de anomolías de la forma y tamaño de la cabeza. A pesar de lo anterior, no existe mucha información de la capacidad craneana en individuos cingaleses. El objetivo de este estudio fue conocer la capacidad craneana en una población adulta de Sri Lanka, para ello fueron incluidos en el estudio 210 sujetos con edades entre 20 y 23 años. La longitud craneal y ancho de la cabeza a nivel auricular fue medido con un caliper digital Todd, con una precisión de $0,01 \mathrm{~mm}$. La capacidad craneana fue calculada utilizando la dimensión externa del cráneo (Lee \& Pearson, 1901; Williams et al., 2000). Los resultados de este estudio indicaron diferencias sexuales significativas en la capacidad craneana media (hombre: $1421.12 \pm 171.69$, mujer: $1300.95 \pm 158.18)$. Se observaron correlaciones positivas entre la capacidad craneana y las dimensiones craneanas. Fueron desarrollos modelos de regresión lineal de predicción de la capacidad craneal para ambos sexos. Los resultados indicaron diferencias tanto raciales y sexuales en la población adulta de Sri Lanka. Estos resultados serán de utilidad en los estudios clínicos, médico-legales, antropológicos y arqueológicos.

PALABRAS CLAVE: Capacidad craneana; Dimensiones lineares; Análisis de regresión; Sri Lanka.

\section{REFERENCES}

Acer, N.; Usanmaz, M.; Tugay, U. \& Ertekin, T. Estimation of cranial capacity in 17-26 year old university students. Int. J. Morphol., 25:65-70, 2007a.

Acer, N.; Sahin, B.; Bas, O.; Ertekin, T.; Usanmaz, M. Comparison of three methods for the estimation of total intracranial volume: stereological, planimetric and anthropometric approaches. Ann. Plast. Surg., 58:48-53, $2007 b$.

Borgognini, Tarli, S. M. \& Repetto, E. Methodological considerations on the study of sexual dimorphism in past human populations. Hum. Evol., 1:51-56, 1986.

Dekaban, A. Tables of cranial and orbital measurements, cranial volume and derived indices in males and female from 7 days to 20 yrs of age. Ann. Neurol., 2:485-9, 1977.

del Sol, M. Índice Cefálico en un grupo de individuos mapuches de la IX región de Chile. Int. J. Morphol., 23:241-6, 2005.

Gault, D.; Brunelle, F.; Renier, D. \& Marchac, D. The calculation of intracranial volume using CT scans. Childs. Nerv. Syst., 4:271-3, 1988.

Golalipour, M. J.; Haisarik, J. M.; Farahani, R. M. The shapes of head and face in normal male newborns in South-East of Caspian sea (Iran-Gorgan). J. Anat. Soc. India., 52:28-31, 2003.

Golalipour, M. J.; Jahanshaei, M. \& Haidari, K. Estimation of cranial capacity in 17-20 years old in South East of Caspian Sea Border (North of Iran). Int. J. Morphol., 23:301-4, 2005.

Haack, D. C. \& Meihoff, E. C. A method for estimation of cranial capacity from cephalometric Roentgenograms. Am. J. Phys. Anthropol., 34:447-52, 1971.

Harper, C.; Krill, J.; Raven, D. \& Jones, N. Intracranial cavity volume: a new method and its potential applications. Neuropathol. Appl. Neurobiol., 10:25-32, 1984.

Hwang, Y.; Lee, K. H.; Choi, B.; Lee, K. S.; Lee, H. Y.; Sir, W. S.; Kim, H. J.; Koh, K. S.; Han, S. H.; Chung, M. S.; et al. Study on the Korean adult cranial capacity. J. Korean Med. Sci., 10:239-42, 1995.

Knutson, B.; Momenan, R.; Rawlings, R. R.; Fong, G. W. \& Hommer, D. Negative association of neuroticism with brain volume ratio in healthy humans. Biol. Psychiatry, 50:685-90, 2001.

Krishan, K. Anthropometry in forensic medicine and forensic science-"forensic anthropometry". Int. J. of Forensic Science, 2:1-18, 2007.

Lee, A. \& Pearson, K. Data for the problem of evolution in man: VI. A first study of the correlation of the human skull. Philos. Trans. R. Soc. London., 196:225-64, 1901.

Manjunath, K. Y. Estimation of cranial volume-an overview of methodologies. J. Anat. Soc. India, 51:8591, 2002a.

Manjunath, K. Y. Estimation of cranial volume in dissecting room cadavers. J. Anat. Soc. India, 51:168-72, 2002 b.

Mazonakis, M.; Karampekios, S.; Damilakis, J.; Voloudaki, A .\& Gourtsoyiannis, N. Stereological estimation of total intracranial volume on CT images. Eur. Radiol., 14:1285-90, 2004.

Mayhew, T. M. \& Olsen, D. R. Magnetic resonance imaging (MRI) and model-free estimates of brain volume determined using the Cavalieri principle. $J$. Anat., 178:133-44, 1991. 
McIntyre, G. T. \& Mossey, P. A. Size and shape measurement in contemporary cephalometrics. Eur. J. Orthodontics., 25:231-42, 2003.

Ricklan, D. E. \& Tobias, P. V. Unusually low sexual dimorphism of endocranial capacity in a Zulu cranial series. Am. J. Phys. Anthropol., 71:285-93, 1986.

Thomas, I. M.; Janaliram, S.; Rajangam, S. \& Amar, D. S. Cranial capacity of crania from Kamatalka. J. Anat. Soc. India, 29:135-7, 1980.

Vojdani, Z.; Bahmanpour, S.; Momeni, S. Vasaghi, A.; Yazdizadeh, A.; Karamifar, A.; Najafifar, A.; Setoodehmaram, S. \& Mokhtar, A. Cephalometry in 1418 years old girls and boys of Shiraz-Iran high school. Int. J. Morphol., 27:101-4, 2009.

Williams, P. L.; Bannister, L. H.; Berry, M. M. Collins, P.; Dyson, M. \& Dussek, J. E. Gray's Anatomy: The anatomical basis of medicine and surgery. $38^{\text {th }}$ Ed. New York, Churchill Livingstone, 2000.

Wolf , H.; Kruggel, F.; Hensel, A.; Wahlund, L. O.; Arendt, T. \& Gertz, H. J. The relationship between head size and intracranial volume in elderly subjects. Brain Res., 973:74-80, 2003.
Correspondence to:

Dr. Isurani llayperuma, Ph.D. Department of Anatomy

Faculty of Medicine

University of Ruhuna

P.O.Box 70

Galle

SRI LANKA.

Telephone: 0094-91-2234801

Fax: 0094-91-2222314

E-mail: iisurani@yahoo.com

Received: 23-10-2010

Accepted: 22-03-2011 